J. Amer. Soc. Hort. ScI. 127(5):860-868. 2002.

\title{
Rainfall Governs Pecan Stand Homogeneity in Native, Wild Habitats
}

\author{
Darrell Sparks ${ }^{1}$ \\ Department of Horticulture, University of Georgia, Athens, GA 30602
}

\begin{abstract}
AdDitional INDEX wORDs. Carya illinoinensis, climate, distribution, ecology, riverine, soils
Aвstract. The relationship was analyzed between historical annual rainfall and pecan [Carya illinoinensis (Wangenh.) K. Koch] homogeneity in selected hardwood populations along two river systems in the native habitat of the species. Tree species other than pecan (sympatric species) were more abundant with increasing rainfall in that the more homogenous pecan populations were located in geographic areas with the least rainfall. These results are the first to establish that pecan stand homogeneity across geographic areas is inversely related to the amount of annual rainfall. Variation in soil texture within geographic areas was also strongly correlated with variation in pecan homogeneity and pecan density. Pecans occur principally on loamy bottom lands and grow on clayey bottom lands in less abundance. A hypothesis related to growth partitioning between root and shoot is proposed to account for pecan's survival advantage, and thus higher stand homogeneity, with decreasing rainfall in native pecan areas. Conversely, the decrease in stand homogeneity with increasing rainfall is proposed to be due to increased forestation of sympatric species on clayey sites that are not optimum for pecan. Across the rainfall gradients, pecan's shade intolerance is suggested to be minimized by differential site requirements for pecan and its sympatric species.
\end{abstract}

Pecan (Carya illinoinesis) is a monoecious, heterdichogamous, wind-pollinated, deciduous tree species indigenous to the United States. The native range follows the river bottoms of the Mississippi River and its tributaries and the rivers of central and eastern Texas and their tributaries (Flack, 1970; U.S. Dept. Agr. Bureau of Plant Industry, 1931). Within its natural range, pecan grows on the lowestlying portions of river bottoms which are termed first bottoms. Pecans are uncommon on second bottoms (Putnam and Bull, 1932; Skinner et al., 1938). Second bottoms are old flood plains that are situated at higher elevations than first bottoms. Unless protected by dams, first bottoms, in contrast to second bottoms, are subject to flooding and often have a relatively high water table. Flooding frequency varies greatly with location and ranges from one or more times annually to as infrequently as once ever 15 years or more (Greenwade et al., 1984; Huckabee et al., 1977).

Pecan is sensitive to poor soil drainage (Alben, 1958; Loustalot, 1945; Smith and Bourne, 1989). Prolonged flooding during dormancy is not detrimental but extended flooding during active tree growth, and especially during budbreak, greatly suppresses shoot and root growth (Smith and Bourne, 1989). Thus, distribution of pecans within first bottoms varies with soil drainage. Drainage is governed largely by the topography and soil texture of the bottom land. High, predominantly loamy ridges occur near the river and low, predominantly clayey flats occur further back. The flats can be intersected by low and, usually, loamy ridges. Ridges are better drained due to higher elevation and loamy soil texture. Flats are often wet due to poor surface drainage which is accentuated by tight clays. Pecans occur principally and are most abundant on welldrained loamy ridges near rivers that are not subject to prolonged overflows (Putnam et al., 1960). Within flats, pecan distribution is restrictive. Pecan is most common on the low, loamy ridges (Putnam et al., 1960) and, on the flat proper, pecan abundance and productivity diminishes progressively as soil drainage decreases (Baker, 1979; Skinner et al., 1938). On low, poorly to very poorly drained clayey flats, pecan is rare (Putnam and Bull, 1932; Putnam et al., 1960; Skinner et al., 1938) and these sites are occupied by tree species other than pecan (Michaux, 1904; Putnam and Bull, 1932;

Received for publication 5 Mar. 2001. Accepted for publication 16 Apr. 2002. Technical assistance of Gloria Belvan is gratefully acknowledged. Appreciation is expressed to Michael W. Smith and Ida E. Yates for critical reviews.

${ }^{1}$ Professor.
Rosborough et al., 1946). In addition to wetness as such, pecan productivity is reduced on loamy sites subject to frequent flooding that results in constant changing of soil scouring and deposition patterns (Baker, 1979).

Because pecan is native to river bottoms, pecan is assumed commonly have a high water requirement (Boisen and Newlin, 1910; Rosborough et al., 1946), and this has been confirmed experimentally (Miyamoto, 1983; Worthington et al., 1987). Therefore, pecans do not grow well on soils with a low available water capacity; that is, shallow soils or excessively drained sandy and gravelly soils (Baker, 1979) or on loamy bottoms in semiarid regions where the water table is apparently beyond pecan's rooting depth (Blum, 1982). These relationships indicate that pecan in its native habitat is site sensitive. Accordingly, pecan tree size and homogeneity increase sharply with suitability of site (Wolstenholme, 1979).

Pecan's native habitat ranges from semiarid to humid climates. On native, undisturbed sites, pecan in places can vary from almost pure, open stands in drier climates(Moore etal., 1977; Wolstenholme, 1979) to stands that are reportedly mixed with other tree species in dense forests in more humid climates (Crenwelge et al., 1981). Gradations in stand mix suggest pecan homogeneity in native pecan areas may vary with long-term annual rainfall. Therefore, the purpose of this study was to examine the relationship between stand homogeneity of pecan in its native habitat and long-term annual rainfall within two river systems in Texas.

\section{Materials and Methods}

Study site. The geographic sites analyzed in this study were the Brazos River System from Proctor (lat. 31 ${ }^{\circ} 58^{\prime} \mathrm{N}$, long. $98^{\circ} 30^{\prime} \mathrm{W}$ ) to Freeport (lat. $28^{\circ} 59^{\prime} \mathrm{N}$, long. $95^{\circ} 23^{\prime} \mathrm{W}$ ), Texas and the Colorado River System from Junction (lat. $30^{\circ} 26^{\prime} \mathrm{N}$, long. $99^{\circ} 48^{\prime} \mathrm{W}$ ) to Wharton (lat. $29^{\circ} 19^{\prime} \mathrm{N}$, long. $96^{\circ} 6^{\prime} \mathrm{W}$ ), Texas as photographed by Maggio et al. (1991). The Brazos River System included portions of Leon, Little, and Brazos rivers. The Colorado River System included the Llano and Colorado rivers. Using the river as a flight line, a single pass was made while taking more than 1,760 aerial photographs for the Brazos River System and 1,500 aerial photographs for the Colorado River System. Each photograph included about $1 \mathrm{~km}$ on either side of the river which encompassed portions 
of, if not all, first bottoms. The study area in the Brazos River System included $896 \mathrm{~km}$ of river; the Colorado River System included 727 $\mathrm{km}$. Along the Brazos river bottoms, the depth of water table ranges from about 0.5 to $15 \mathrm{~m}$ but is mostly $<9 \mathrm{~m}$ (Cronin and Wilson, 1967). Depth and variation of the water table along the Colorado river bottoms appear similar to that on the Brazos (Baker, 1979; Rayner, 1958; Turner, 1938). Both river systems encompassed a water table of 2.5 to $6.0 \mathrm{~m}$, considered ideal for pecan in its native habitat (Wolstenholme, 1979).

Maggio et al. (1991) georeferenced the aerial photography by use of the Universal Transverse Mecator grid system (Maggio et al., 1982). The Brazos River System was divided into five geographic areas and the Colorado River System was divided into six geographic areas (Maggio et al., 1991). The area photographed and thus the size of study sites varied according to the length of the river within each (Fig. 1) geographic area. The 11 geographic areas were used as the basis units (Fig. 1) for examining the potential relationship of pecan stand homogeneity to rainfall.

DETERMINATION OF PECAN STAND HOMOGENEITY AND PECAN TREE DENSITY. Pecan homogeneity and density were based on previously published data (Maggio et al., 1991). Carya Nutt. sp. present were $C$. illinoinensis, $C$. aquatica (Michx. f.) Nutt. (water hickory), $C$. tomentosa Nutt. (mockernut hickory), C. ovata (Mill.) Koch (shagbark hickory), and C.cordiformis (Wangenh.) Koch (pignuthickory). The predominant species was $C$. illinoinensis. In the upper regions of both rivers, C. illinoinensis constituted $98 \%$ or more of the Carya sp. and in the lower regions the percentage was $\geq 90 \%$ (M. K. Harris, personal communication). Consequently, all Carya trees were assumed to be pecan in the previous (Maggio et al., 1991) and in the present study. In the study of Maggio et al. (1991), native pecan was identified in two categories: native pecan groves and native (wild) pecan forests. Native pecan groves were areas that had been cleared by humans of competing trees and brush and used for commercial nut production. Further cultural inputs are minimal except for nut harvesting (Sparks, 1980). Native pecan forests were areas left in the wild where pecan was intermixed with other trees species (sympatric species) in a closed canopy (Maggio et al., 1991). The closed canopy is characteristic of forested conditions and infers minimally, if any, human disturbance.

Pecan stand homogeneity for the forest and pecan tree density for native pecan forests or pecan groves were calculated by geographic area from data of Maggio et al. (1991). These workers measured hectares of ground containing pecans and hectares of ground covered by pecan canopy in native pecan groves and in native pecan forests. Additionally, in native pecan forests, hectares of ground covered by sympatric species canopy were quantified. Pecan stand homogeneity was calculated as percentage pecan canopy of the total canopy existing in the forest. Native pecan density in forests or groves was calculated as the ratio of hectares occupied by pecan canopy to ground area occupied by pecans in the entire forest or grove.

Calculation of rainfall. Average annual rainfall for 1964-97 (National Climatic Data Center, 1964-97), calculated for recording stations located in close proximity to the rivers, was used as an estimate of historical rainfall. Most stations were $\leq 16 \mathrm{~km}$ from the river, but five were 19 to $23 \mathrm{~km}$ from the river. The earliest record common to all stations was the year 1964. Stations used for the Brazos River System were Angleton, Belton Dam, Brenham, Caldwell, Cameron, College Station, Freeport, Gatesville, Hico, Killeen, Proctor Reservoir, Richmond, Rockdale, Temple, Thompsons, and Waller, Texas. Rainfall stations for the Colorado River System were Austin, Burnet, Columbus, Junction, LaGrange,
Llano, Mason, Pierce, Round Mountain, Round Rock, Smithville, Spicewood, Telegraph, and Wharton, Texas. Number of recording stations within each geographic area varied from one to four.

CANOPY AREA AND SOIL CHARACTERISTICS IN STUDY SITES. Hectares of canopy occupied by pecan in groves, by pecan in forests, and by sympatric tree species in forests were correlated with hectares of river bottom land having specific soil characteristics; that is, pecan site index, land capability class, and texture. A site index is a numerical expression used by foresters to judge the quality of a forest site based on the height of the dominant and codominant trees in a fully stocked stand at the arbitrarily chosen age of 50 years. For example, if the average height of pecan trees at age 50 is $23 \mathrm{~m}$, the site index is $23 \mathrm{~m}$ (Baker, 1979). Pecan site index within the study areas ranged from 15 to $23 \mathrm{~m}$ depending on soil type. Land capability classes indicate the suitability of soils for crops. Classes range from I, well suited for cultivation, to VIII, unsuited for any kind of commercial plant production (Greenwade et al., 1996). Land capability classes II to VIII may have four subclasses that indicate the type of limitation encountered: risk of erosion, $e$; wetness or frequently flooded, $w$; low water availability due to shallow soils or to excessively drained sandy or gravelly soils $s$; and climatic limitations, such as short growing season $c$. Within the study areas, classes ranged from I to VI.

Soils were divided into three categories. The first category was soils with a pecan site index of 21 to $23 \mathrm{~m}$, or the soils most suited for pecan growth. All the soils were loamy and well drained. The second category consisted of clayey and loamy soils in land capability class IV to VI and soils in subclass $w$ regardless of capability class. Soils in class IV were predominantly (88\%) in subclass $s$, that is, gravelly or shallow. In class V and VI, the soils were mainly in subclass $w, 99.5 \%$ and $100 \%$, respectively. Of the soils in subclass $w$, the $w$ designation was due primarily to poor surface drainage and a resultant high water table $(\leq 1 \mathrm{~m})$ which occurred mainly in winter and early spring, frequent flooding, or both. Thus, soils in the second category are less suited for pecan due to either inadequate soil moisture, excessive soil moisture, or frequent flooding. The third category was the same as the second category except the soils were all clayey. Correlations of canopy and soil characteristics were restricted to soil types on which pecan is native, regardless of degree of suitability of the soil type for pecan or to the degree that the area was covered with pecan or sympatric species. Canopy and soil areas were expressed as hectares per kilometer of river to eliminate variation in canopy and in soil area associated with differences in river length among geographic areas. Within each geographic area, river length was restricted to sectors in which native pecans occurred. Soils with a site index of 21 to $23 \mathrm{~m}$, clayey and loamy soils in class IV to VI and subclass $w$, or clayey soils in class IV to VI and subclass $w$ were not significantly correlated $(P \leq 0.01)$ with total river bottom land per kilometer of river, $r^{2}=0.10,0.36$, and 0.42 , respectively. Thus, the size of the areas in each of the three soil categories is independent of total area of river bottom land. All correlations of canopy and soil characteristics were limited to areas containing counties with soil surveys. Consequently, geographic areas 7 and 10, with incomplete surveys, were excluded.

Calculations made from the data of Maggio et al. (1991) showed that hectares of pecan canopy in the forest were 2.7 times greater in the Brazos River System than in the Colorado River System, 2,154 and 808 ha, respectively. Similarly, hectares of pecan canopy in native groves were 2.5 times greater on the Brazos than on the Colorado, 3337 and 1362 ha, respectively. Similarity of the ratios, 2.7 and 2.5 , suggest that differences in hectares of pecans on the two river systems are not due to differential clearing of forest for row 


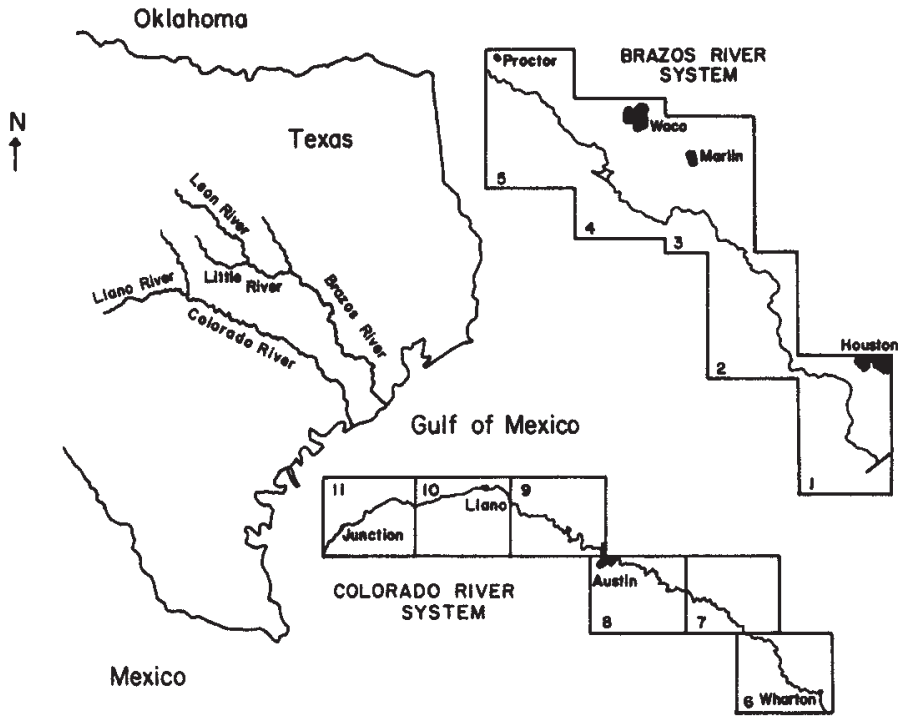

Fig. 1. Geographic areas along the Brazos River and Colorado River Systems in Texas (adapted from Maggio et al., 1991) used as the basis units for examining the relationship of pecan homogeneity to annual rainfall.

crops. The one exception, geographic area 3, is discussed later. Had differential clearing occurred, the ratios would be dissimilar. Similarity of ratios justifies combining the data for the two rivers into one data set.

DAta Analysis. Data means were analyzed by analysis of variance. Trends were delineated by simple correlations and by simple and multiple regression analysis (Snedecor and Cochran, 1967).

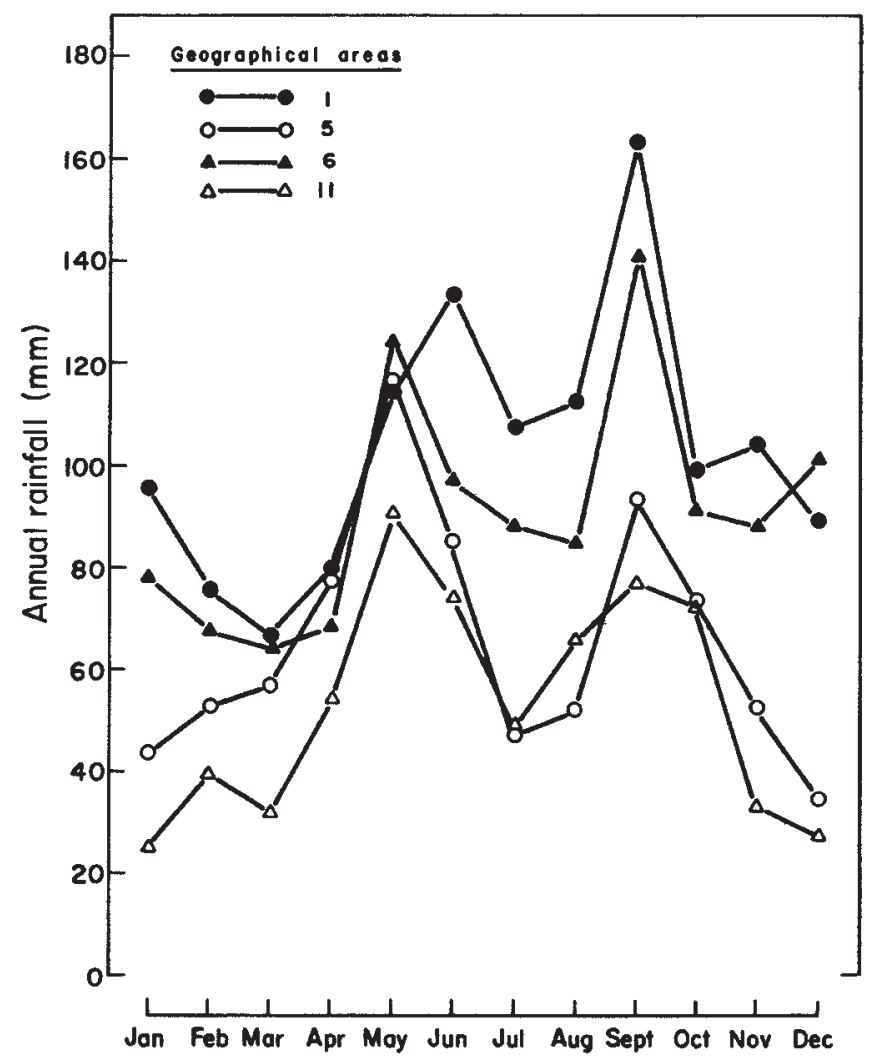

Fig. 2. Long-term seasonal rainfall in humid vs. semiarid areas. Areas 1 and 5 are humid and semiarid areas, respectively, in the Brazos River System. Areas 6 and 11 are humid and semiarid areas, respectively, in the Colorado River System. Numbers within the figure designate geographic areas. See legend for Fig. 1.

\section{Results}

WATER RELATIONSHIPS TO PECAN STAND HOMOGENEITY AND PECAN TREE DENSITY. Long-term annual rainfall for geographical areas 1 to 5 (Fig. 1) along the Brazos River was 1300, 1070, 970, 880, and 830 $\mathrm{mm}$, respectively. For areas 6 to 11 (Fig. 1) on the Colorado River, rainfall was 1110, 1030, 910, 830, 700, and $660 \mathrm{~mm}$, respectively. From down to up stream on both rivers, the rainfall gradient was from humid to semiarid. Areas on the Colorado were more arid than those on the Brazos. During the growing season of April to October, rainfall distribution was bimodal with a peak in May and again in September along both river systems (Fig. 2).

Percentage pecan canopy in the total forest was lowest in geographic areas with the highest annual rainfall so that pecan stands became more homogenous with a decrease in annual rainfall (Fig. 3). The percentage of total tree canopy in the forest occupied by pecan decreased from 35 to 17 as long-term annual rainfall increased from 660 to $1300 \mathrm{~mm}$ (Fig. 3). Thus, within native sites, homogeneity of pecan stands was highest in semiarid climates and lowest in humid climates. Geographic area 3 was an outlier and was not used in the regression analysis. Exploration of the land use history for this area may explain the reason area 3 did not fit the relationship determined for the other areas. During the 1800 s, the bottom lands were cleared to grow cotton (Gossypium hirsutum L) (Carter et al., 1925). Only a few pecan trees were left standing (J.B. Storey, personal communication) as documented

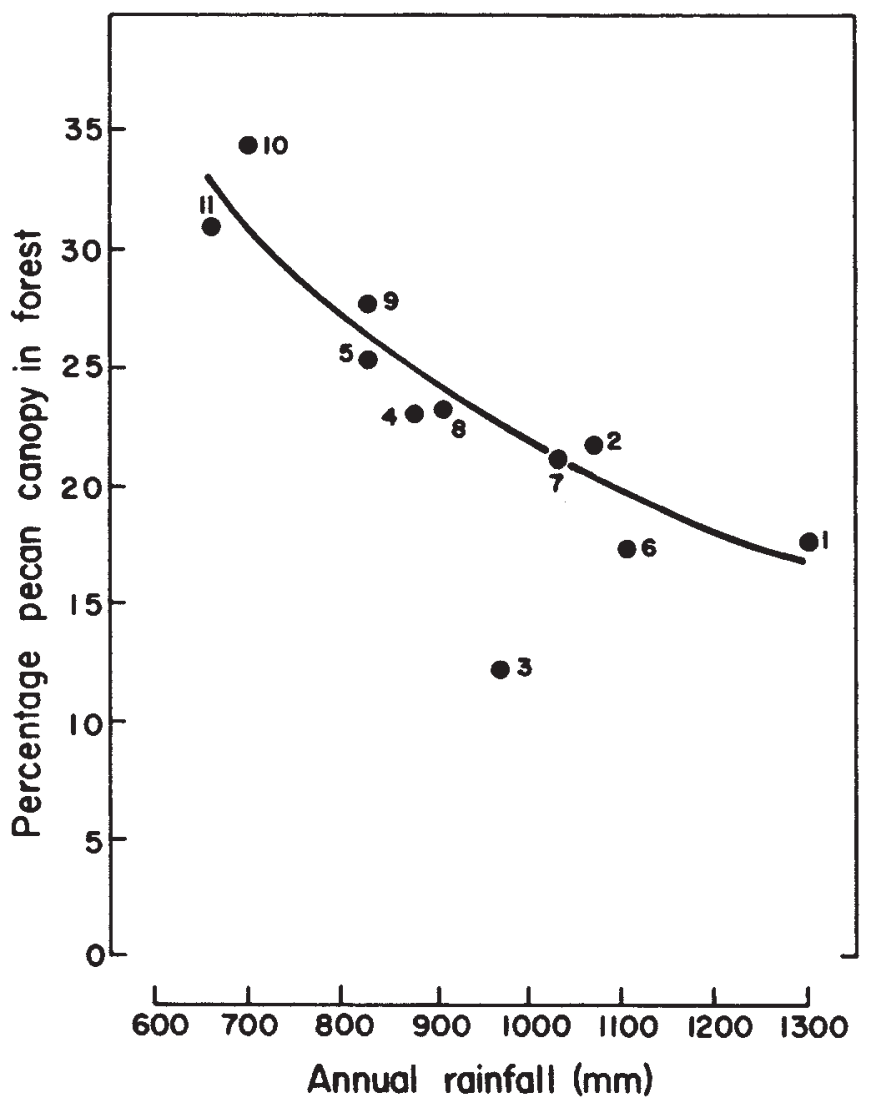

Fig. 3. Relationship of pecan canopy as percentage of total canopy in forests along the Brazos and Colorado River Systems in Texas to long-term annual rainfall. Pecan canopy and canopy of sympatric species were measured as hectares of ground covered by each. The relationship is described by $\log \mathrm{Y}=3.3360-0.4341$ natural $\log \mathrm{X}, r^{2}=0.90, \mathrm{SE}= \pm 0.03$. The regression coefficient is statistically significant from zero, $P \leq 0.01$. Numbers within the figure designate geographic areas. See legend for Fig. 1. Observation for area 3 is excluded from the equation. See text. 


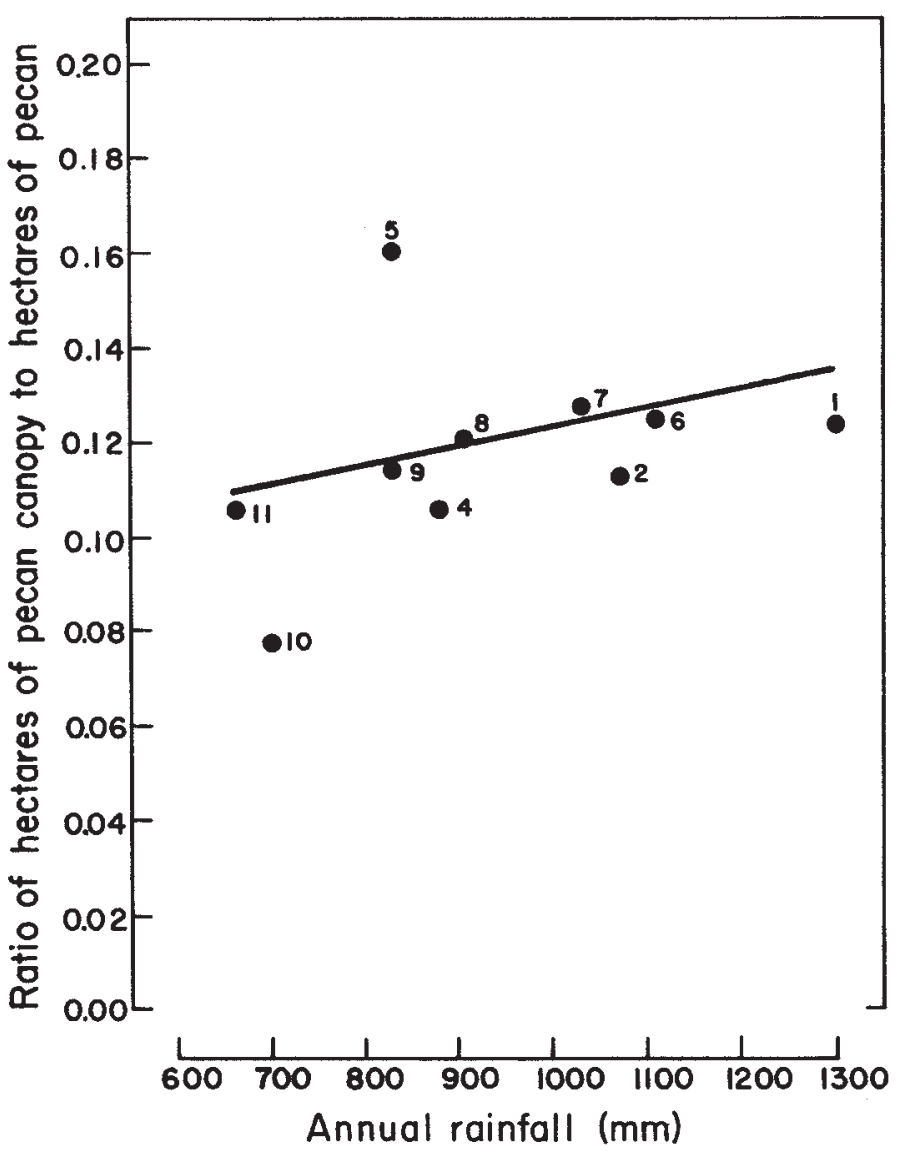

Fig. 4. Ratio of hectares of pecan canopy to hectares containing pecans in the forest as a function of annual rainfall. The relationship follows $\mathrm{Y}=0.0838+0.0004 \mathrm{X}$, $r^{2}=0.20, \mathrm{SE}= \pm 0.0210$. The regression coefficient is not statistically significant from zero, $P \leq 0.01$. Numbers within the figure designate geographic areas. See legend for Fig. 1.

numerically (Maggio et al., 1991). The river bottom land in area 3 has a high percentage of land capability class I soil, up to $90 \%$ depending on the county (Mowery et al., 1958). The percentage of land capability class I soil in the other counties within the two river systems was much lower averaging only $20 \%$ with a range of $0 \%$ to 49\% among counties (Baker, 1979; Blum, 1982; Chervenka et al., 1981; Crenwelge et al., 1981; Dittemore and Allison, 1979; Greenwade et al., 1984, 1996; Huckabee et al., 1977; McCaleb et al., 1985; McEwen and Crout, 1974; Moore et al., 1977; Mowery et al., 1960). The high percentage of land capability class I soil in area 3 was no doubt a major incentive to clear the forest. Thus, the native habitat for area 3 was substantially altered and therefore was not included in the calculation of the regression line and is excluded from further consideration.

Pecan tree density in the forest was not significantly affected by annual rainfall (Fig. 4). Pecan tree density was statistically greater $(P \leq 0.01)$ in native groves than in the native pecan forest, 0.15 and 0.11 , respectively. Most probable, the density calculated for groves is an underestimate because competing trees are removed during the conversion of a pecan forest to a grove (Maggio et al., 1991).

SOIL CHARACTERISTICS RELATED TO PECAN STAND HOMOGENEITY AND PECAN TREE DENSITY. Canopy of pecan in native groves (Fig. 5) increased with hectares of loamy bottom land with a pecan site index of 21 to $23 \mathrm{~m}$. Canopy of pecan in the forest (Fig. 6) and canopy of sympatric species in the forest (Fig. 7) were not correlated with soils having a pecan site index of 21 to $23 \mathrm{~m}$. Canopy of pecan in the forest

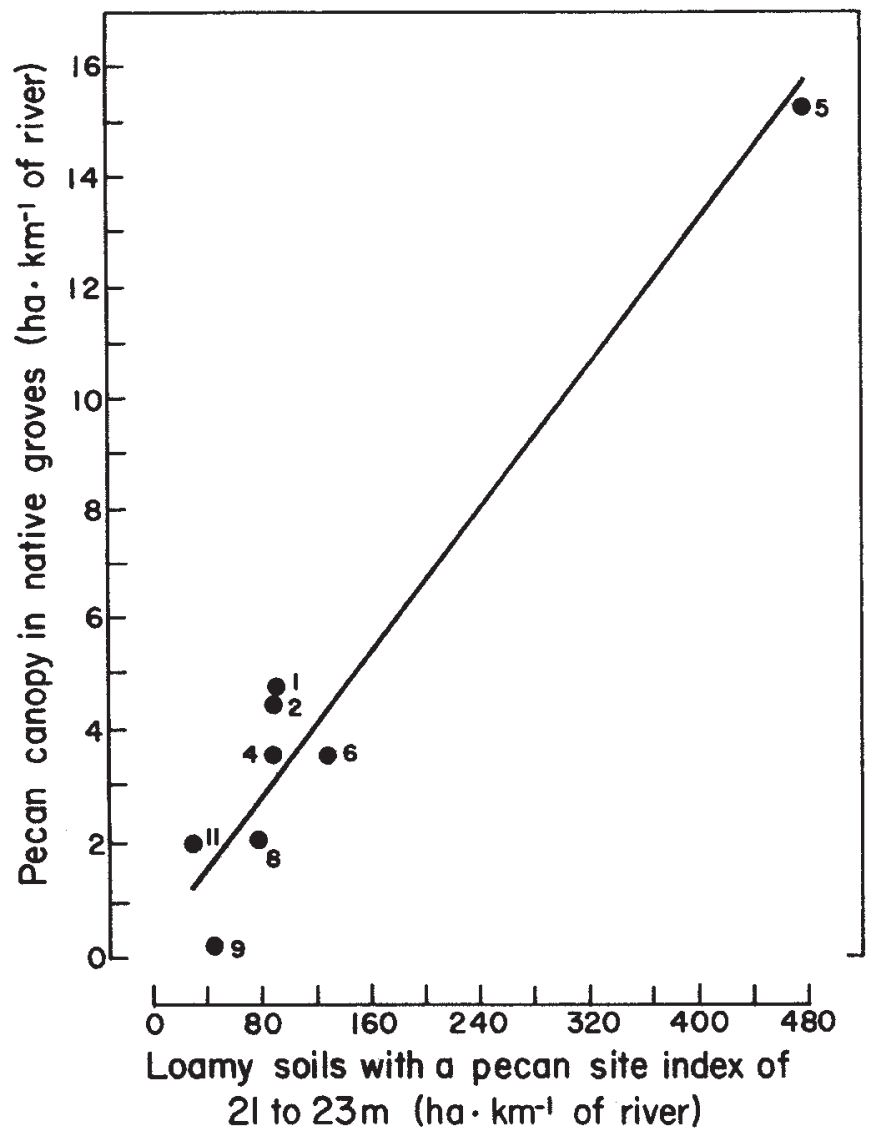

Fig. 5. Relationship of hectares of pecan canopy in native groves to loamy soils with a pecan site index of 21 to $23 \mathrm{~m}$. The relationship is depicted by $\mathrm{Y}=0.3743$ $+0.0314 \mathrm{X}, r^{2}=0.94, \mathrm{SE}= \pm 1.20$. The regression coefficient is statistically significant from zero, $P \leq 0.01$. Numbers within the figure designate geographic areas. See legend for Fig. 1. Hectares of loamy soils were from county soil surveys. Data within geographic areas are limited to counties (Austin, Bastrop, Bell, Brazoria, Burnet, Comanche, Coryell, Fort Bend, Kimble, Travis, Waller, Washington, and Wharton, Texas) with soil surveys.

was highly correlated with clayey and loamy soils in land capability class IV to VI and subclass $w$ soils (Fig. 8). Canopy of sympatric species in the forest was correlated with clayey soils in capability class IV to VI and subclass $w$ soils (Fig. 9) but to a lesser degree than was pecan canopy and capability class (Fig. 8). Canopy of pecan's sympatric species in the forest was correlated with clayey soils in land capability class IV to VI and subclass $w$ soils and with rainfall (Fig.10). The multiple correlation (Fig.10) was substantially higher than the simple correlation of sympatric species canopy and capability class (Fig.9). In contrast to sympatric species canopy (Fig. 10), canopy of pecan increased with clayey and loamy soils but not with rainfall (Fig. 11). The regression coefficients for all relationships were less than unity. Less than unity values occurred because the relationships were based on soils on which pecan was native regardless of the degree of soil suitability or to the degree that the area was covered with pecan or sympatric species.

\section{Discussion}

The flora along the Colorado and Brazos River Systems vary with rainfall. In the semiarid regions of both river systems, grasses are the major vegetation type forming a prairie habitat with only $10 \%$ to $25 \%$ of the ground covered by a canopy of pecan and other tree species. As the humidity increases, trees become more common 


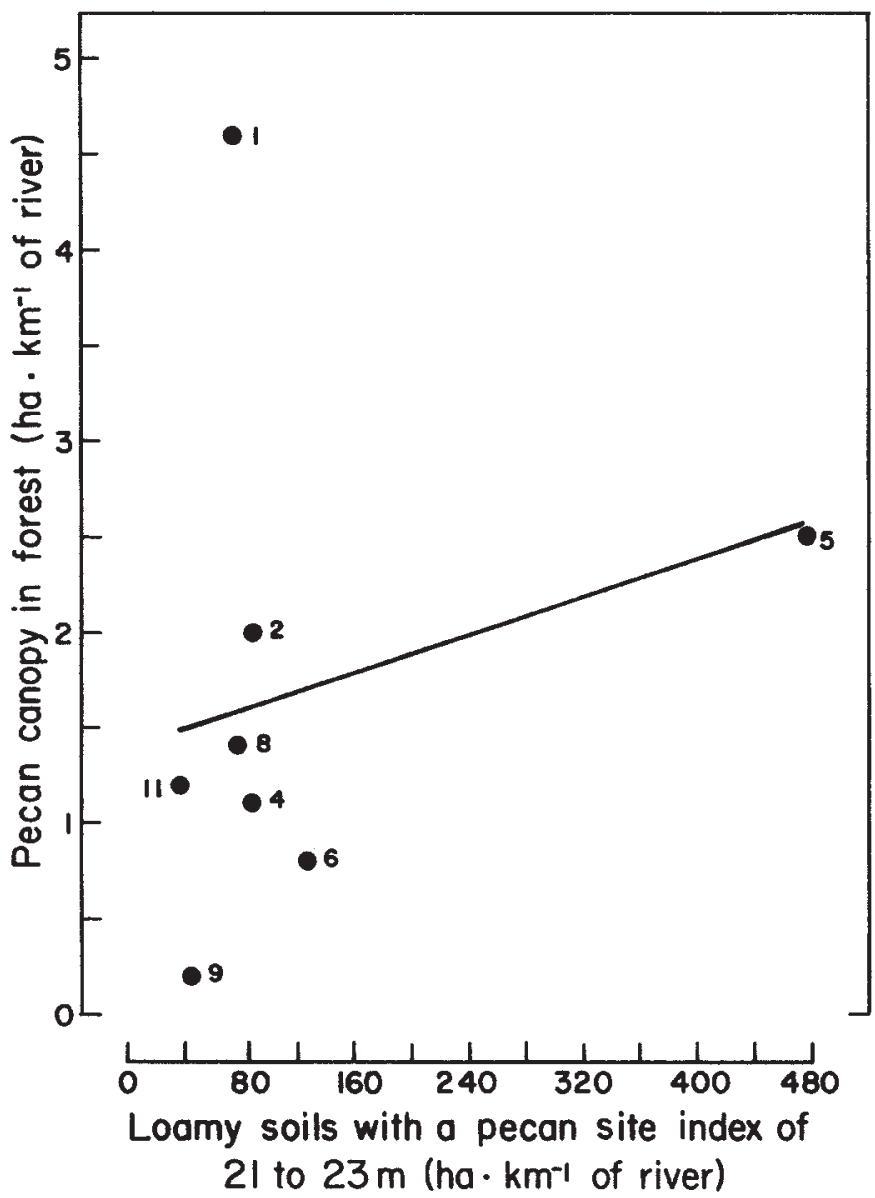

Fig. 6. Relationship of hectares of pecan canopy in the forest to loamy soils with a pecan site index of 21 to $23 \mathrm{~m}$. The relationship is depicted by $\mathrm{Y}=1.3979+$ $0.0025 \mathrm{X}, r^{2}=0.07, \mathrm{SE}= \pm 1.41$. The regression coefficient is not statistically significant from zero, $P \leq 0.01$. Numbers within the figure designate geographic areas. See legend for Fig. 1. Hectares of loamy soils were from county soil surveys. Data within geographic areas are limited to counties (Austin, Bastrop, Bell, Brazoria, Burnet, Comanche, Coryell, Fort Bend, Kimble, Travis, Waller, Washington, and Wharton, Texas) with soil surveys.

and shrubs and forbs become the primary ground cover. Hackberry (Celtis occidentalis L.), american elm (Ulmus americana L.), sycamore (Platanus occidentails L.), eastern cottonwood (Populus deltoides Bartr.), and black willow (Salix nigra Marsh.) are the dominant sympatric tree species occurring in the semiarid areas. As the areas become more humid, additional sympatric species include green ash (Fraxinus pennsylvanica Marsh.), white ash (Fraxinus americana L.), sugarberry (Cletis lavigata Willd.), willow oak (Quercus phellos L.), and water oak (Quercus nigra L.) (Baker, 1979; Bennett and Shaw, 1909; Blum, 1982; Chervenka et al., 1981; Crenwelge et al., 1981; Dittemore and Allison, 1979; Greenwade et al., 1984, 1996; Huckabee et al., 1977; McCaleb et al., 1985; McEwen and Crout, 1974; Moore et al., 1977; Mowery et al., 1960). The predominant forest cover types (Society of American Foresters, 1954) from semiarid to humid climates are cottonwood, sycamorepecan-american elm, and sugarberry-american elm-green ash. Pecan and sympatric species grow best on river bottoms (Fowells, 1965) indicating high water use as shown for pecan (Miyamoto, 1983; Worthington, 1987), sycamore, willow, and cottonwood (Lee, 1942).

The relationships demonstrated between soil characteristics with the canopy covers of pecans in groves, pecans in forests, and

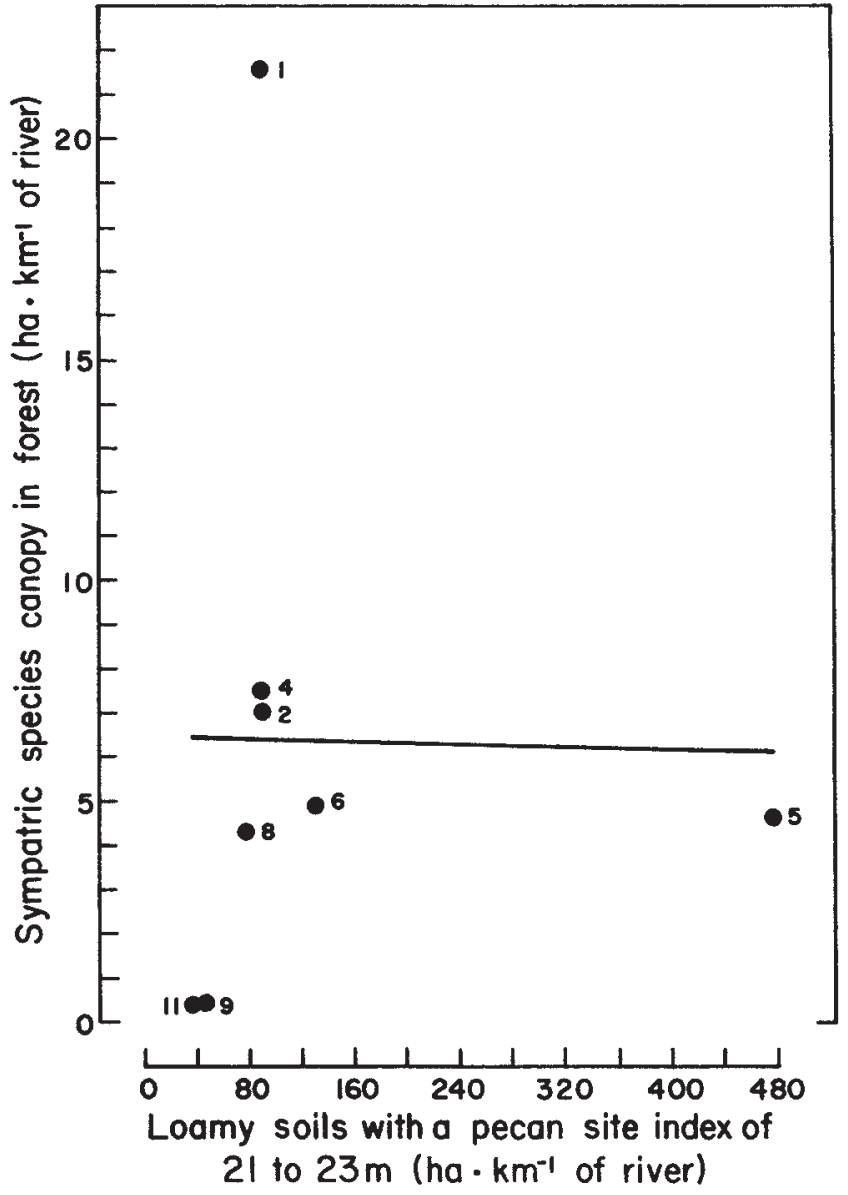

Fig. 7. Relationship of hectares of canopy of pecan's sympatric species in the forest to loamy soils with a pecan site index of 21 to $23 \mathrm{~m}$. The relationship is depicted by $\mathrm{Y}=6.4455-0.0008 \mathrm{X}, r^{2}=0.00, \mathrm{SE}= \pm 7.2$. The regression coefficient is not statistically significant from zero, $P \leq 0.01$. Numbers within the figure designate geographic areas. See legend for Fig. 1. Hectares of loamy soils were from county soil surveys. Data within geographic areas are limited to counties (Austin, Bastrop, Bell, Brazoria, Burnet, Comanche, Coryell, Fort Bend, Kimble, Travis, Waller, Washington, and Wharton, Texas) with soil surveys.

sympatric species in forest (Figs. 5 to 9) have several implications. Pecan in its native habitat is most common on well-drained loamy ridges in first bottoms (Putnam and Bull, 1932; Putnam et al., 1960). These sites were more likely to be selected by growers for native pecan groves simply because tree homogeneity was more apt to be sufficient for commercial nut production. Thus, pecan canopy in native groves would be expected to be highly correlated with welldrained loamy soils (Fig. 5) or the soils most suited for pecan growth but poorly correlated $(P \leq 0.01)$ with either clayey and loamy $\left(r^{2}=\right.$ $0.16)$ or clayey $\left(r^{2}=0.04\right)$ soils in class IV to VI and subclass $w$, soils less fitted for pecan growth. Pecans in the forest were not correlated with well-drained loamy soils (Fig. 6) but were well correlated with soils less suited for pecan (Fig. 8). These relationships suggest that the pecan forests in this study are relegated to soils less desirable for commercial pecan production. This contention is supported by comparison of pecan tree density in groves vs. forests. Tree density was statistically greater in native groves than in native pecan forests, 0.15 vs. 0.11 , indicating that the denser areas originally in the wild were converted to groves and the least dense areas were left in the wild. The high correlation of sympatric species canopy with clayey soils (Fig. 9) and the lack of a correlation with well-drained loamy soils (Fig. 7) implies sympatric species occur predomi- 


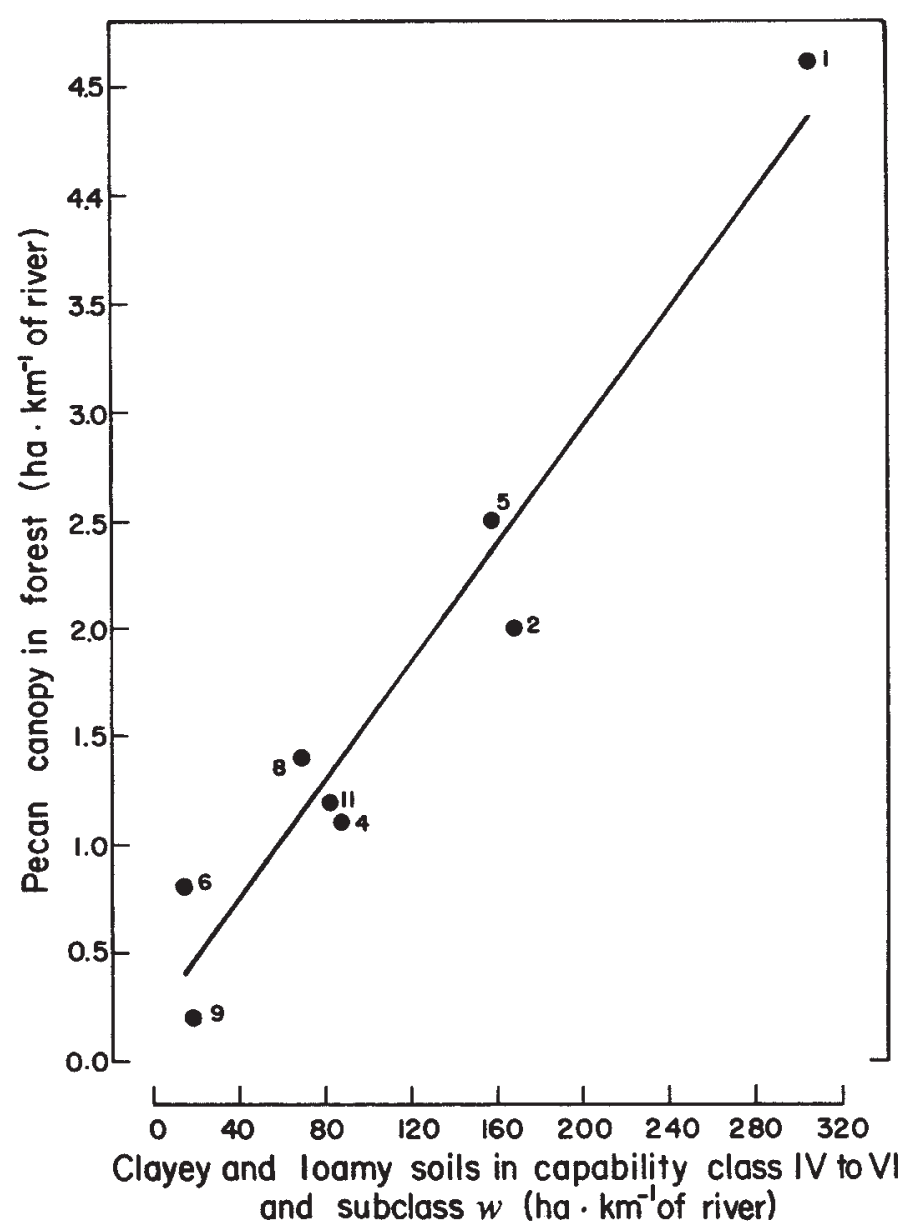

Fig. 8. Relationship of hectares of pecan canopy in the forest to clayey and loamy soils in land capability class IV to VI and subclass $w$ soils. The relationship is depicted by $\mathrm{Y}=0.1943+0.0134 \mathrm{X}, r^{2}=0.95, \mathrm{SE}= \pm 0.34$. The regression coefficient is statistically significant from zero, $P \leq 0.01$. Numbers within the figure designate geographic areas. See legend for Fig. 1. Hectares of clayey and loamy soils in land capability class IV to VI and subclass $w$ soils were from county soil surveys. Data within geographic areas are limited to counties (Austin, Bastrop, Bell, Brazoria, Burnet, Comanche, Coryell, Fort Bend, Kimble, Travis, Waller, Washington, and Wharton, Texas) with soil surveys.

nantly on clayey soils. Overall, the relationships in Figs. 5 to 9 suggest the occurrence of pecan vs. sympatric species is strongly associated with soil type in local sites. The correlations confirm the contention of Putnam and Bull (1932). They proposed, based on observations, that on Mississippi Delta bottom land there is a strong relationship between soils and forest species in general.

FACTORS RESPONSIBLE FOR THE RELATIONSHIP BETWEEN RAINFALL AND PECAN STAND HOMOGENEITY. Three factors can be considered responsible for the relationship between pecan stand homogeneity and the amount of rainfall. These factors are 1) the relationship between pecan root and shoot growth during the early years following seed germination, 2) minimization of pecan's shade intolerance by differential site requirements for pecan and its sympatric species within river bottom land and, 3) increased forestation of sympatric species on clayey sites with rainfall. Following pecan seed germination, the taproot may be 1 to $2 \mathrm{~m}$ at season's end (Toumey, 1929; Woodroof, 1933) while shoot growth is limited to about 12 to $30 \mathrm{~cm}$ (Boisen and Newlin, 1910; Sparks, 1986a, 1986b; Toumey, 1929; Wetzstein et al., 1983). Only after the root system becomes established does substantial top growth occur, sometime after the fourth growing season (Boisen and Newlin, 1910). During the first few years after germination, the taproot continues to grow vertically.

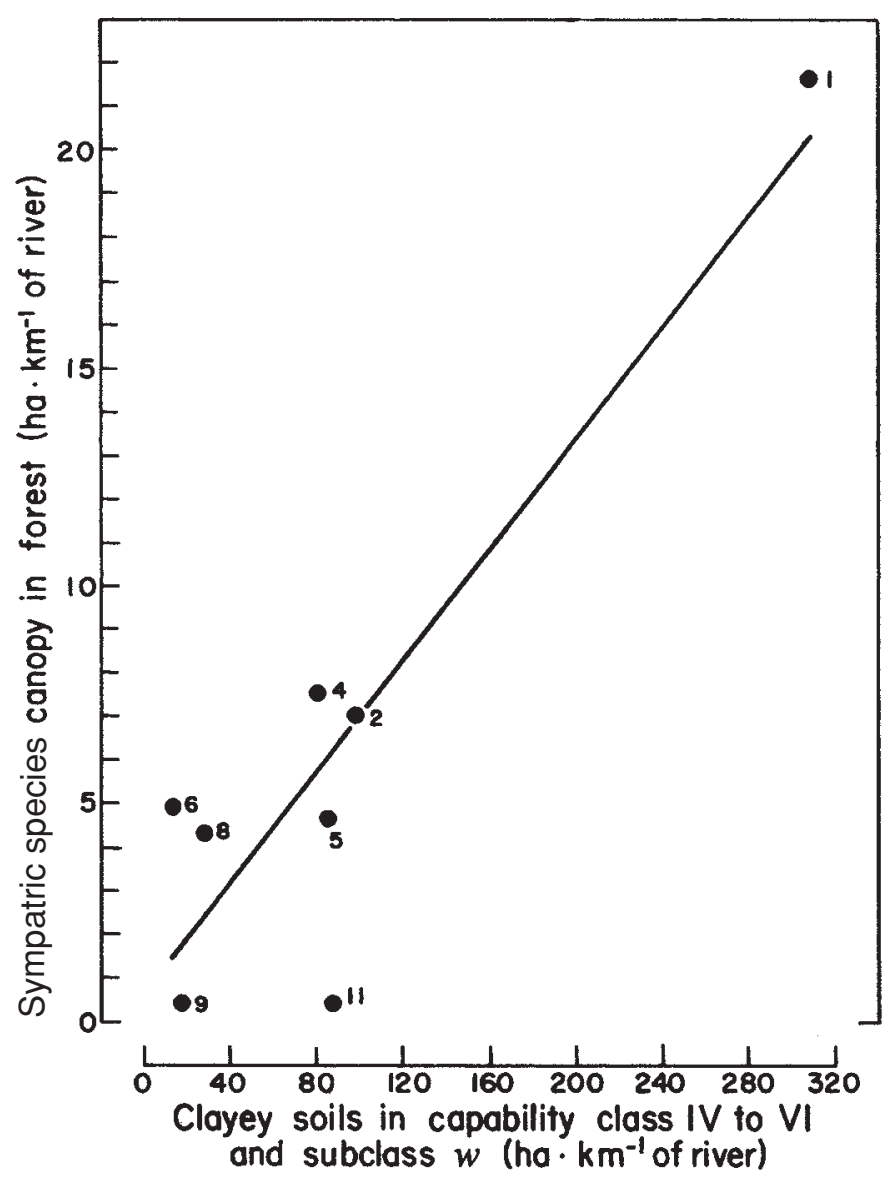

Fig. 9. Relationship of hectares of canopy of pecan's sympatric species in the forest to clayey soils in land capability class IV to VI and subclass $w$ soils. The relationship is depicted by $\mathrm{Y}=0.6150+0.0636 \mathrm{X}, r^{2}=0.82$, SE $= \pm 3.1$. The regression coefficient is statistically significant from zero, $P \leq 0.01$. Numbers within the figure designate geographic areas. See legend for Fig. 1. Hectares of clayey soils in land capability class IV to VI and subclass $w$ soils were from county soil surveys. Data within geographic areas are limited to counties (Austin, Bastrop, Bell, Brazoria, Burnet, Comanche, Coryell, Fort Bend, Kimble, Travis, Waller, Washington, and Wharton, Texas) with soil surveys.

Final rooting depth varies with soil depth and drainage (Alben, 1955; Gammon et al., 1955; Kerzdorn, 1952; U.S. Dept. Agr. Bureau of Plant Industry, 1931; White andEdwards, 1978; Woodroof and Woodroof, 1934), but roots of mature trees may extend to a depth of at least $7 \mathrm{~m}$ (Kerzdorn, 1952) or down to the water table. Because of its great rooting depth, pecan in its native habit can be classified as a phreatophyte, a plant that characteristically roots down to the water table.

Partitioning of growth between the root and shoot provides pecan with an adaptive survival mechanism in the semiarid regions of its native range. In native pecan river bottoms, the water table varies during the year being highest during the winter months or early spring (Greenwade et al., 1984). The soil water table typically descends deeper into the soil as the growing season progresses from spring until fall. Floods, occurring mainly in late fall, winter, and early spring (Smith and Bourne, 1989), rainfall, and runoff from uplands (Rosborough et al., 1946) tend to accentuate the variation in soil moisture during the year. Accelerated rains in early spring (Fig. 2) or receding flood waters ensure surface soil moisture during the April to May nut germination period. Following germination, pecan has a survival advantage over shallow-rooted tree species in semiarid regions because pecan's continuous and downward root penetration keeps ahead of the descending and seasonal desiccation 


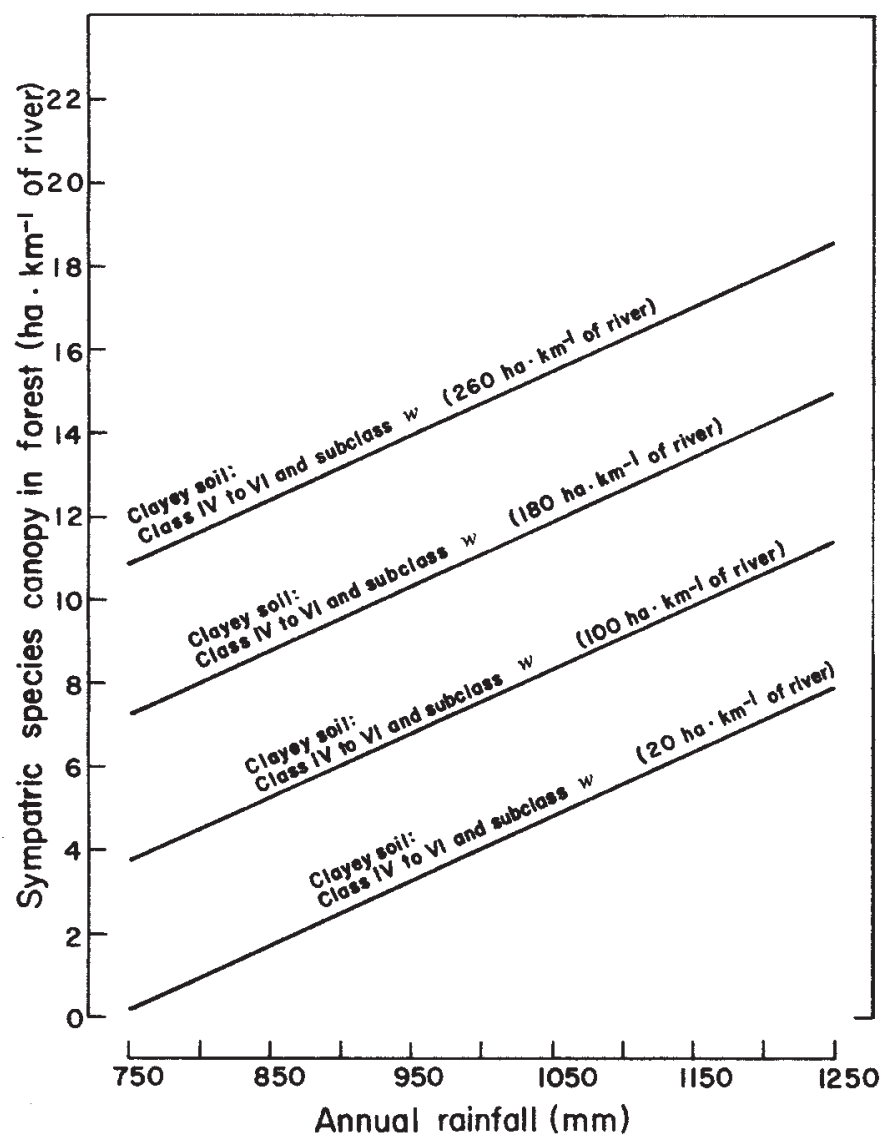

Fig. 10. Relationship of hectares of canopy of pecan's sympatric species in the forest to rainfall and clayey soils in land capability class IV to VI and subclass $w$ soils. The relationship is depicted by $\mathrm{Y}=-12.2269+0.1534 \mathrm{X}_{1}+0.0446 \mathrm{X}_{2}$ where $\mathrm{X}_{1}$ is rainfall and $\mathrm{X}_{2}$ is soil, $R^{2}=0.96$, $\mathrm{SE}= \pm 1.7$. The regression coefficients are statistically significant from zero, $P \leq 0.01$. Numbers within the figure designate geographic areas. See legend for Fig. 1. Hectares of clayey soils in land capability class IV to VI and subclass $w$ soils were from county soil surveys. Data within geographic areas are limited to counties (Austin, Bastrop, Bell, Brazoria, Burnet, Comanche, Coryell, Fort Bend, Kimble, Travis, Waller, Washington, and Wharton, Texas) with soil surveys.

of the soil profile. Thus, the pecan seedling has a continuous water supply for growth that is not available to shallow-rooted tree species. The continuous downward root growth increases the probability of pecan seedling establishment under semiarid conditions. The annual cycle of soil moisture replenishment from flooding, rain and/ or winter rise of the water table continues to give pecan trees survival advantage over shallow-rooted tree species in the years following initial seedling establishment. Deep alluvial soils of the native pecan range can retain large volumes of water. For example, pecan's seasonal water requirement of 1000 to $1300 \mathrm{~mm}$ (Miyamoto, 1983; Worthington et al., 1987) can be stored in a 6 m deep soil with an available water holding capacity of $2.1 \mathrm{~mm} \cdot \mathrm{cm}^{-1}$. The utility of the large and deep soil volume occupied by pecan roots and/or relatively high water table is evident from independence of stand density on long-term rain (Fig. 4); that is, density is the same in semiarid and humid areas. Significance of the large and deep soil volume occupied by pecan roots becomes especially evident during prolonged droughts. Pecan tree survival during the severe, extended drought in the 1950s increased directly with rooting depth (Alben, 1955). Consequently, in semiarid climates, pecan stand homogeneity is higher than in humid climates (Fig. 3) because, long term, the deeprooted pecan out survives shallow-rooted tree species. Sympatric tree species in the semiarid regions, sycamore, willow, cottonwood

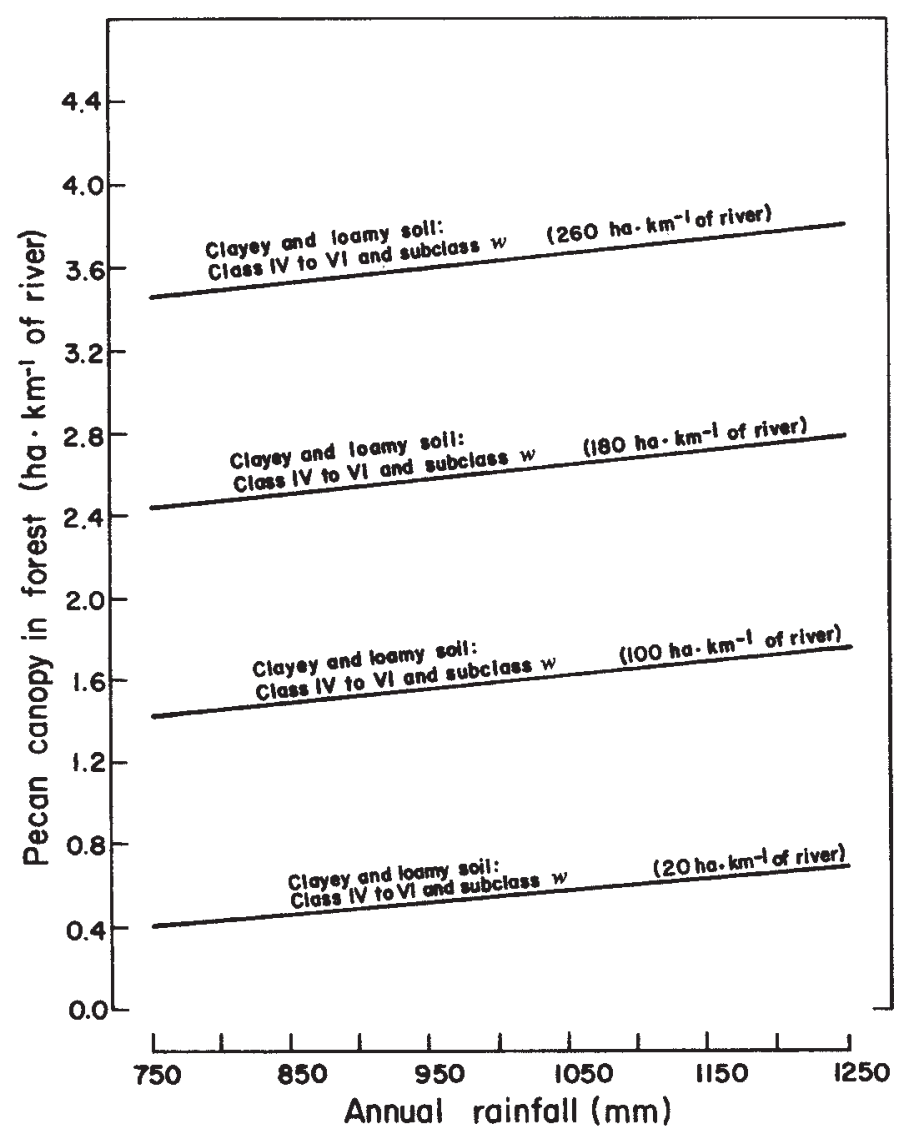

Fig. 11. Relationship of hectares of pecan canopy in the forest to rainfall and clayey and loamy soils in land capability class IV to VI and subclass $w$ soils. The relationship is depicted by $\mathrm{Y}=-0.3449+0.0066 \mathrm{X}_{1}+0.0127 \mathrm{X}_{2}$ where $\mathrm{X}_{1}$ is rainfall and $\mathrm{X}_{2}$ is soil, $R^{2}=0.95, \mathrm{SE}= \pm 0.3$. The regression coefficient for $\mathrm{X}_{2}$ but not for $\mathrm{X}_{1}$ is statistically significant from zero, $P \leq 0.01$. Numbers within the figure designate geographic areas. See legend for Fig.1. Hectares of clayey and loamy soils in land capability class IV to VI and subclass $w$ soils were from county soil surveys. Data within geographic areas are limited to counties (Austin, Bastrop, Bell, Brazoria, Burnet, Comanche, Coryell, Fort Bend, Kimble, Travis, Waller, Washington, and Wharton, Texas) with soil surveys.

(Lee, 1942), and american elm (Hayes and Stoeckeler, 1935) like pecan are phreatophytes. Except for willow (Toumey, 1929) and cottonwood (Lee, 1942), which are shallow rooted and grow on sites with a shallow water table (Fowells, 1965), the other sympatric species, american elm (Clements et al., 1929), sycamore (Biswell, 1935), and hackberry (Hayes and Stoeckeler, 1935) are deep rooted like pecan.

Rooting depth, as such, is not the sole determinant in establishment of pecan and its sympatric tree species in river bottom prairies. The consensus is that establishment of pioneer trees along prairie river bottoms requires soil scouring or deposition by flood water or other natural causes that bare the ground of grass (Albertson and Weaver, 1945; Clements et al., 1929; Fowells, 1965). The consensus is supported by the bare, wet ground required for germination and survival of black willow, cottonwood, and sycamore seedlings (Fowells, 1965; Putnam et al., 1960) and that american elm and green ash establish poorly, if at all, in prairie grass (Clements et al., 1929; Pearson, 1936).

Typically, black willow and eastern cottonwood are the first pioneer trees growing on newly formed land on the river edge. Willows are near the river edge; cottonwoods are farther back and on higher and drier ground. Both endure long flooding and sedimentation (Putnam, 1932). Sycamores often develop under 
and eventually replace willow and cottonwood (Fowells, 1965; Putnam, 1932). American elm rarely establishes on bare ground. Both american elm and hackberry establish in under story where they complete well due to their shade tolerance. American elm and hackberry are most common on poorly drained clay flats or clay ridges within the river bottom and are uncommon on loamy ridges (Putnam et al., 1960). Thus, american elm and hackberry are not major competitors for pecan sites. Observations in meadows suggest the large-seeded pecan in contrast to small-seeded sympatric species can establish in grass. These observations are supported by the successful establishment of the similarly largeseeded shagbark hickory in prairie grass (Holch, 1931). However, soil souring or major sedimentation by flooding may be major factors in pecan stand establishment as with black willow, cottonwood, and sycamore. Either germination and survival in grass or establishment on bare ground following major flooding in semiarid regions could account for essentially pure pecan stands on loamy well-drained ridges with willows, cottonwood, and sycamore, predominantly situated on wet sites near the river and hackberry and american elm predominantly on clay flats. Differential positioning of pecan on the river bottom (Putnam et al., 1960) would eliminate or minimize potential shade during the seedling stage from the much more vigorous seedlings of willow, sycamore, hackberry, and american elm (Fowells, 1965). Thus, the shade intolerance of pecan (Baker, 1950; Boisen and Newlin, 1910; Putnam and Bull, 1932) is not a major survival obstacle in semiarid regions. More vigorous but shallow-rooted sympatric species that could shade out pecan are stunted or die of lack of water or else they occupy different and noncompeting sites on river bottom land.

In humid regions, soil moisture in the upper soil profile is more plentiful throughout the growing season and the lag phase of shoot growth is potentially a major disadvantage because pecan seedlings are more likely to be shaded out by additional sympatric species with more vigorous shoot growth, regardless of rooting depth. With increasing rainfall along both the Brazos and Colorado River Systems, green ash and further on, in more humid areas, water and willow oaks, white ash, and sugarberry become additional dominant sympatric species. All of these species are more vigorous during the first few years following germination than pecan (Fowells, 1965). The additional sympatric species, green ash, willow oak, sugarberry, like american elm and hackberry, are predominantly situated on clay flats. White ash grows best on loamy ridges on second bottoms. Water oak, like pecan, grows best on loamy ridges on first bottoms (Fowells, 1965; Putnam and Bull, 1932) and, consequently, may compete with pecan for loamy sites. However, for the most part, potential shading of pecan seedlings by sympatric tree species in humid climates, as in semiarid climates, is minimized by differential positioning of sympatric tree species on noncompeting sites on river bottom land. On apparent loamy sites in humid and semiarid areas, pecan's successful competition for sunlight is evidenced by tree stands sufficiently dense for commercial pecan production (Maggio et al., 1991).

In humid areas, pecan's shade intolerance is more likely to be an establishment hazard on well-drained clay flats due to the more vigorous growth of and increased shading from sympatric species that are more suited to these sites than pecan. Shading may account in part for pecan trees being less abundant on welldrained clayey sites (Baker, 1979; Huckabee et al., 1977; Werchan et al., 1974). Pecan (Putnam et al., 1960) and hickories in general (Keever, 1973; Peet and Christensen, 1980) need disturbances that produce prolonged openings or light gaps in the forest to become established successfully. Otherwise, hickory species (Ranney et al., 1981; Sork, 1983) including pecan are forest edgeoriented. In humid Georgia where pecan is an introduced species, pecan seedlings become established along the forest edge and in open fields but rarely within a mature forest. On clayey sites, pecan's shade intolerance should become an increasing establishment disadvantage with rainfall due to increased inclusion of sympatric species with greater stand density than occurs in low rainfall regions. Such can be surmised from the increase in the canopy of sympatric species on clayey soils with rainfall (Fig. 10). Pecan canopy in the forest did not change with rainfall (Fig. 11) again suggesting the independence of stand establishment on rainfall. The lower tree density (ratio of hectares of pecan canopy to hectares containing pecan) in the forest than in native groves, 0.11 vs. 0.15 , may be due in part to differential shade competition of pecans growing on loamy (Fig. 5) vs. an apparent mixture of loamy and clayey (Fig. 8) sites in the forest. From the relationship in Fig. 10, competition from sympatric species would be minimal on clayey sites in semiarid areas. Consequently, under semiarid conditions, pecan could become extensively established on a well-drained clay soil as is the case (Blum, 1982). Nevertheless, with increasing humidity, pecan establishment on well-drained clayey sites would be expected to become increasing dependent on prolonged light gaps.

Reduced pecan homogeneity with an increasing humid climate (Fig. 3) appears to be due mainly to increased forestation of river bottom sites that are not optimum for pecan. Such is supported by the stability of pecan stands across geographical areas (Fig. 4), the apparent dominance of pecan on loamy soils (Fig. 5), and the increase of forest canopy on clayey soils with rainfall (Fig. 10). Pecan stand stability also indicates, that on river bottom sites suitable for pecan, the rate of pecan population recruitment is similar across the rainfall gradient from semiarid to a humid climate. The stability of stand density over wide geographical areas suggests pecan in its natural habitat is a climax and not a subclimax species as suggested by Fowells (1965).

Although long-term rainfall does not directly influence stand density, seasonal rainfall is expected to directly affect tree growth and productivity once stand establishment occurs. The March to May increase in rainfall coincides with the grand flush of shoot elongation and leaf expansion. The August to September elevation in rainfall co-occurs with kernel development (Fig. 2). Kernel development, most of which occurs within 4 weeks, is critically dependent on adequate soil moisture (Sparks, 1992; 1996).

In summary, tree species other than pecan became more dominant with increasing rainfall in that the more homogenous pecan populations were located in geographic areas with the least rainfall. The deep rooting characteristic of pecan provides an adaptive survival mechanism allowing the species to obtain water under semiarid conditions. Potential shallow rooted, competing species do not survive under these conditions. The decrease in pecan stand homogeneity with rainfall is proposed to be due to increased forestation of sympatric species on clayey sites that are not optimum for pecan. Pecan's shade intolerance is suggested to be minimized by differential site requirements for pecan and its sympatric species. The importance of rooting depth on pecan stand homogeneity in wild, native habitats has direct implications to commercial pecan production. Pecan growth, production, and drought resistance increase directly with soil depth (Gammon et al., 1963, 1955). 


\section{Literature Cited}

Alben, A.O. 1955. Studies on relation of drought injury of pecan to soil textures and profiles. Proc. Texas Pecan Growers Assn. 34:32-38.

Alben, A.O. 1958. Waterlogging of subsoil associated with scorching and defoliation of Stuart pecan trees. Proc. Amer. Soc. Hort. Sci. 72:219-223.

Albertson, F.W. and J.E. Weaver. 1945. Injury and death or recovery of trees in prairie climate. Ecol. Monogr. 15:393-433.

Baker, F.E. 1979. Soil survey of Bastrop County, Texas. U.S. Dept. Agr. Soil Conservation Serv., Wash., D.C.

Baker, F.S. 1950. Principles of silviculture. McGraw-Hill, New York.

Bennett, H.H. and C.F. Shaw. 1909. Soil survey of Robertson County, Texas. U.S. Dept. Agr. Bur. Soils, Wash., D.C.

Biswell, H.H. 1935. Effects of environment upon the root habits of certain deciduous forest trees. Bot. Gaz. 96:676-708.

Blum, E.L. 1982. Soil survey of Kimble County, Texas. U.S. Dept. Agr. Soil Conservation Serv., Wash., D.C.

Boisen, A.T. and J.A. Newlin. 1910. The commercial hickories. U.S. Dept. Agr. For. Serv. Bul. 80.

Carter, W.T., M.W. Beck, E.H. Templin, and H.W. Hawkins. 1925. Soil survey of Milam County, Texas. U.S. Dept. Agr. Bur. Chem. and Soils, Wash., D.C.

Chervenka, W.G., J.J. Castile, M.R. Jurena, and M. Stewart. 1981. Soil survey of Washington County, Texas. U.S. Dept. Agr. Soil Conservation Serv., Wash., D.C.

Clements, F.E., J.E. Weaver, and H.C. Hanson. 1929. Plant competition. Publ. 398. Carnegie Inst., Wash., D.C.

Crenwelge, G.W., J.D. Crout, E.L. Griffin, M.L. Golden, and J.K. Baker. 1981. Soil survey of Brazoria County, Texas. U.S. Dept. Agr. Soil Conservation Serv., Wash., D.C.

Cronin, J.G. and C.A. Wilson. 1967. Ground water in the flood-plain alluvium of the Brazos River, Whitney Dam to vicinity of Richmond, Texas. Texas Water Dev. Board Rpt. 41.

Dittemore, Jr., W.H. and J.E. Allison. 1979. Soil survey of Blanco and Burnet Counties, Texas. U.S. Dept. Agr. Soil Conservation Serv., Wash., D.C.

Flack, J.R. 1970. The spread and domestication of the pecan (Carya illinoensis) in the United States. PhD diss., Univ. Wis., Madison. (diss. abstr. 71-288).

Fowells, H.A. 1965. Silvics of the forest trees of the eastern United States. U.S. Dept. Agr. Hdbk. 271.

Gammon, Jr., N., R.G. Leighty, and R.H. Sharpe. 1963. Estimation of pecan production based on soil site examination and tree size. Proc. Amer. Soc. Hort. Sci. 82:231-236.

Gammon, Jr., N., R.H. Sharpe, and R.G. Leighty. 1955. Relationship between depth to heavy-textured subsoil and drought injury to pecans. Soil Sci. Soc. Fla. Proc. $15: 31-34$.

Greenwade, J.M., W. Crenwelge, R.L. Schlappi, S.G. Hitt, and M. Stewart. 1984. Soil survey of Austin and Waller Counties, Texas. U.S. Dept. Agr. Soil Conservation Serv., Wash., D.C.

Greenwade, J.M., R. Schlappi, B. Smith, and W. Crenwelge. 1996. Soil survey of Grimes County, Texas. U.S. Dept. Agr. Natural Resources Conservation Serv., Wash., D.C.

Hayes, F.A. and J.H. Stoeckeler. 1935. Possibilities of shelterbelt planting in the Plains region. U.S. Dept. Agr. For. Serv. Spec. Bul. p. 111-155.

Holch, A.E. 1931. Development of roots and shoots of certain deciduous tree seedlings in different forest sites. Ecology 12:259-298.

Huckabee, Jr., J.W., D.R. Thompson, J.C. Wyrick, and E.G. Pavlat. 1977. Soil survey of Bell County, Texas. U.S. Dept. Agr. Soil Conservation Serv., Wash., D.C.

Keever, C. 1973. Distribution of major forest species in southeastern Pennsylvania. Ecol. Monogr. 43:313-327.

Kerzdorn, A.H. 1952. A good pecan soil. Proc. Texas Pecan Growers Assn. 31:44-48.

Lee, C.H. 1942. Transpiration and total evaporation, p. 259-330. In: O.E. Meinzer (ed.). Hydrology. McGraw-Hill, New York.

Loustalot, A.J. 1945. Influence of soil moisture conditions on apparent photosynthesis and transpiration of pecan leaves. J. Agr. Res. 71:519-533.

Maggio, R.C., R.D. Baker, and M.K. Harris. 1982. A geographic data base for Texas pecan. Photogrammetric Eng. Remote Sensing 49:47-52.

Maggio, R.C., M.K. Harris, S.J. Ingle, and M.R. Davis. 1991. A summary of the location, abundance, distribution and condition of Carya on the Brazos and Colorado River Systems in Texas. Texas Agr. Expt. Sta. Misc. Publ. 1703.

McCaleb, N.L., E.D. Bearden, L.N. Kiniry, L.T. West, and D.L. Williamson. 1985. Soil survey of Coryell County, Texas. U.S. Dept. Agr. Soil Conservation Serv., Wash., D.C.

McEwen, H.F. and J. Crout. 1974. Soil survey of Wharton County, Texas. U.S. Dept. Agr. Soil Conservation Serv., Wash., D.C.
Michaux, F.A. 1904. Journal of Andre Michaux, 1793-1796, p. 27-306. In: R.G. Thwaites (ed.). Early western travels, 1748-1846. vol. 3. Clark, Cleveland, Ohio. Miyamoto, S. 1983. Consumptive water use of irrigated pecans. J. Amer. Soc. Hort. Sci. 108:678-681.

Moore, J.D., B.W. Kendrick, B.J. Wagner, and E.R. Harris. 1977. Soil survey of Comanche County, Texas. U.S. Dept. Agr. Soil Conservation Serv., Wash., D.C.

Mowery, I.C., G.S. McKee, F. Matanzo, E. Francis, and H. Oakes. 1960. Soil survey of Fort Bend County, Texas. U.S. Dept. Agr. Soil Conservation Serv., Wash., D.C. Mowery, I.C., H. Oakes, J.D. Rourke, F. Matanzo, H.L. Hill, G.S. McKee, B.B. Crozier, and E.H. Templin. 1958. Soil survey of Brazos County, Texas. U.S. Dept. Agr. Soil Conservation Serv., Wash., D.C.

National Climatic Data Center. 1964-97. Climatological data for Texas. Natl. Oceanic Atmospheric Admin., Asheville, N.C.

Pearson, G.A. 1936. Why the prairies are treeless. J. For. 45:405-408.

Peet, R.K. and N.L. Christensen. 1980. Succession: A population process. Vegetatio 43:131-140.

Putnam, J.A. and H. Bull. 1932. The trees of the bottomlands of the Mississippi River Delta Region. S. For. Expt. Sta., New Orleans, La. Occasional Paper 27. Putnam, J.A., G.M. Furnival, and J.S. McKnight. 1960. Management and inventory of southern hardwoods. U.S. Dept. Agr. Hdbk 181.

Ranney, J.W., M.C. Bruner, and J.B. Levenson. 1981. The importance of edge in the structure and dynamics of forest islands, p. 67-95. In: R.L. Burgess and D.T. Sharpe (eds.). Forest island dynamics in man-dominated landscapes. SpringerVerlag, New York.

Rayner, F.A. 1958. Records of water-level measurements in Jackson, Matagorda, and Wharton Counties, Texas, 1934 to April 1958. Texas Board Water Eng. Bul. 5804.

Rosborough, J.F., C.L. Smith, and L.D. Romberg. 1946. The pecan in Texas. Texas Agr. Ext. Serv. Bul. 120.

Skinner, J.J., E.D. Fowler, and A.O. Alben. 1938. Pecan soils of the Gulf and Southeastern States and maintenance of their fertility. U.S. Dept. Agr. Cir. 492. Smith, M.W. and R.D. Bourne. 1989. Seasonal effects of flooding on greenhousegrown seedling pecan trees. HortScience 24:81-83.

Snedecor, G.W. and W.G. Cochran. 1967. Statistical methods. Iowa State Univ. Press, Ames.

Society of American Foresters. 1954. Forest cover types of North America (exclusive of Mexico). Soc. Amer. Foresters, Wash., D.C.

Sork, V.L. 1983. Distribution of pignut hickory (Carya glabra) along a forest to edge transect, and factors affecting seedling recruitment. Bul. Torrey Bot. Club 110:494-506.

Sparks, D. 1980. Energy requirement of pecan, Carya illinoensis (Wang) K. Koch, p. 327-333. In: D. Pimentel (ed.). Handbook of energy utilization in agriculture. CRC Press, Boca Raton, Fla.

Sparks, D. 1986a. Effect of magnesium sulfate sprays on growth and elemental concentration of pecan seedlings. HortScience 21:108-109.

Sparks, D. 1986b. Growth and nutrition of pecan seedlings from potassium phosphate foliar sprays. HortScience 21:452-453.

Sparks, D. 1992. Pecan cultivars: The orchard's foundation. Pecan Production Innovations, Watkinsville, Ga.

Sparks, D. 1996. A climatic model for pecan production under humid conditions. J. Amer. Soc. Hort. Sci. 121:908-914.

Toumey, J.W. 1929. Initial root habit in American trees and its bearing on regeneration. Proc. 4th Intl. Bot. Congr. 1:713-728.

Turner, S.F. 1938. Colorado County, Texas: Records of wells and springs, drillers' logs and water analyses, and map showing location of wells and springs. Texas Board Water Eng., Austin.

U.S. Department of Agriculture Bureau of Plant Industry. 1931. First annual report. Pecan investigations, Austin and Brownwood, Texas. U.S. Dept. Agr. Bur. Plant Ind., Wash., D.C.

Werchan, L.E., A.C. Lowther, and R.N. Ramsey. 1974. Soil survey of Travis County, Texas. U.S. Dept. Agr. Soil Conservation Serv., Wash., D.C.

Wetzstein, H.Y., D. Sparks, and G.A. Lang. 1983. Cotyledon detachment and growth of pecan seedlings. HortScience 18:331-333.

White, A.W. and J.H. Edwards. 1978. Soil profile distribution and seasonal growth of pecan roots. Proc. S.E. Pecan Growers Assn. 71:47-53.

Wolstenholme, B.N. 1979. The ecology of pecan trees. part 1. Characteristics of the native habitat. Pecan Quart. 13(2):32-35.

Woodroof, J.G. 1933. Relation of the root system of pecan trees to nursery and orchard practices. Ga. Expt. Sta. Bul. 176.

Woodroof, J.G. and N.C. Woodroof. 1934. Pecan root growth and development. J. Agr. Res. 49:511-530.

Worthington, J.W., J. Lasswell, and M.J. McFarland. 1987. Irrigation: The trees' prospective. Pecan S. 21(1):4-8. 